\title{
Characterization of Alternaria Species Causing Early Blight of Tomato
}

\author{
K. P. Ragupathi ${ }^{1 *}$, P. R. Renganayaki ${ }^{1}$, S. Sundareswaran ${ }^{1}$, \\ S. Mohan Kumar ${ }^{2}$ and A. Kamalakannan ${ }^{3}$ \\ ${ }^{1}$ Department of Seed Science \& Technology, TNAU, Coimbatore, India \\ ${ }^{2} C P M B \& B, T N A U$, Coimbatore, India \\ ${ }^{3}$ Department of Plant Pathology, TNAU, Coimbatore, India \\ *Corresponding author
}

\section{A B S T R A C T}

\section{Ke y w o r d s \\ Tomato, \\ Early blight, \\ Alternaria solani, \\ Alternaria alternata \\ Article Info \\ Accepted: \\ 18 November 2020 \\ Available Online: \\ 10 December 2020}

The present study aims at isolation, identification and characterization of different isolates of Alternaria spp from early blight infected seed samples collected at different regions of Tamilnadu. Four different isolates of Alternaria spp were obtained in pure culture which were designated as isolate PKM-CBE, PKM-DHR, PKM-DKL and PKM - KKR. Significant morphological variations in length and breadth of conidia, numbers of horizontal, vertical and oblique separations were observed in the test isolates. Isolates produce cotton mycelia growth with pigmentation varied from yellow, brown, and grey on potato dextrose agar medium. The PCR amplification of the fungal DNA using universal primers ITS1 and ITS4 and sequencing indicated that, isolates PKM-CBE, PKM-DHR, PKM-DKL were Alternariasolani and isolate PKM - KKR was Alternaria alternata. Pathogenicity test on tomato indicated that both Alternaria spp isolates were virulent.

\section{Introduction}

Tomato (Solanum lycopersicum Mill.) is one of the most popular vegetable crops grown globally. Alternaria is a cosmopolitan fungus and is the causal organism of leaf blight diseases in Cucurbitaceous and Solanaceous vegetables and accounted for $78 \%$ yield loss at $72 \%$ disease intensity (Datar and Mayee, 1981). The pathogen of the disease is reported as Alternaria solani (Alhussan, 2012; Derbalah et al., 2011; Kumar et al., 2008) and Alternaria alternata (Murugan et al., 2014; Bhatt et al., 2008). Characterization of pathogen based on virulence is mandatory to develop appropriate management practices. Identification of early blight pathogen is generally based on conidial morphology under specific media, temperature, relative humidity and light (Kumar et al., 2008). Genetic identification is progressively used to identify the pathogens (Bridge et al., 2004) and internal transcribed spacer (ITS) rRNA has been successfully employed to identify the fungal pathogens at species level (Bowmann et al., 2007). In the present study, Alternaria early blight infected tomato samples collected from diverse locations of 
Tamilnadu were used to characterize Alternaria spp. based on cultural characteristics, pathogenic potentiality and ITS region.

\section{Materials and Methods}

Early blight infected tomato seed samples were collected from different regions of Tamilnadu and pure pathogen cultures were isolated on potato dextroseagar (PDA) and subsequently purified by single hyphal tip method. The cultures were transferred on PDA slants and incubated at $25 \pm 2{ }^{\circ} \mathrm{C}$ under alternate light/darkness (12 h each) for $72 \mathrm{~h}$ and were stored at $4^{\circ} \mathrm{C}$ for further use. Koch's postulates were tested for all the cultures.

\section{Characterization based on Culture and Spore Morphology}

Pure cultures of isolates were individually transferred onto PDA in petri dishes and incubated at $25 \pm 2^{\circ} \mathrm{C}$. After 9 days, the cultures were observed for morphological characters viz., culture colour, growth pattern and spore morphological studies. The culture plates were incubated at $25 \pm 2^{\circ} \mathrm{C}$ under alternate light/darkness (12 h each). After 9 days, for each culture, the spore morphologies were observed under microscope (Murugan et al., 2014)

\section{Molecular Characterization}

\section{DNA Extraction}

Fungal isolates were grown on potato dextrose broth at $25 \pm 2^{\circ} \mathrm{C}$ for 10 days. DNA was extracted from the cultures. Mycelium of the cultures was taken out by filtration through Whatman No. 1 filter paper and washed thoroughly in distilled water and properly dried. $3 \mathrm{~g}$ of mycelium was macerated along with liquid nitrogen with the help of mortar and pestle and transferred into a centrifuge tube and added with $15 \mathrm{~mL}$ of
CTAB buffer (2\% (w/v) CTAB, $1.4 \mathrm{M} \mathrm{NaCl}$, $20 \mathrm{mM}$ EDTA, $100 \mathrm{mM}$ Tris-HCl, pH 8.0,1 $\%$ PVP, $1 \%$ (v/v) 2-mercaptoethanol). The mixture was incubated at $65^{\circ} \mathrm{C}$ in a water bath for $30 \mathrm{~min}$ with intermittent shaking and the entire content was centrifuged at13,000 rpm for $10 \mathrm{~min}$ at $4^{\circ} \mathrm{C}$. The supernatant was transferred into a fresh Oakridge tube and an equal volume of Phenol:Chloroform: Isoamylalcohol (25:24:1) was slowly added to it. Again, the content was centrifuged at $13,000 \mathrm{rpm}$ for $10 \mathrm{~min}$ at $4^{\circ} \mathrm{C}$. The supernatant was transferred into a fresh tube and added with 0.6 volume isopropanol and incubated overnight at $-20^{\circ} \mathrm{C}$. On the following day, it was again centrifuged at $13,000 \mathrm{rpm}$ for $10 \mathrm{~min}$ at $4^{\circ} \mathrm{C}$ temperature. The pellet was retained and supernatant was discarded. The pellet was briefly washed with $75 \%$ ethanol and dried at room temperature. Finally the pellet was dissolved in $100 \mu \mathrm{L}$ of TE buffer and kept at $-20^{\circ} \mathrm{C}$ for further use.(Manicom et al., 1987)

\section{PCR}

The fungal DNA was amplified using universal internal transcribe spacer region (ITS) primers (ITS1-TCCGTAGGTGAACC TGCGG and ITS4-TCCTCCGCTTATTGAT ATGCA) as described by (White et al., 1990). The PCR reaction was carried out in a Thermocycler with 35 cycles of denaturation for $1 \mathrm{~min}$ at $94^{\circ} \mathrm{C}$, primer annealing for $45 \mathrm{~s}$ at $55^{\circ} \mathrm{C}$ and primer extension for $1 \mathrm{~min} 30 \mathrm{~s}$ at $72^{\circ} \mathrm{C}$, with an initial denaturation at $94^{\circ} \mathrm{C}$ for $3 \mathrm{~min}$ and a final extension for $15 \mathrm{~min}$ at $72^{\circ} \mathrm{C}$. The reaction was carried out in a volume of 25 $\mu \mathrm{L}$ containing $1 \mu \mathrm{L}$ DNA template, $1.5 \mathrm{U} p f u$ DNA polymerase, $25 \mathrm{mM} \mathrm{MgCl} 2,2 \mathrm{mM}$ dNTPs and 25 pmol of each primer. PCR products were electrophoresed $(1 \mathrm{~h}$ at 80 volts) in $0.8 \%$ agarose gel in Tris-borateEDTA buffer at $\mathrm{pH} 8$. Gels were stained with ethidium bromide $(10 \mu \mathrm{g} / \mathrm{mL})$ and viewed in Gel documentation system. 


\section{Cloning of PCR product and sequencing}

The PCR amplified product was excised from gel and purified by Gel extraction kit and cloned. Recombinant clones were sequenced with automated sequencer at Barcode Bio Sciences India Pvt. Ltd DNA Sequencing facility, Banglore, India.

\section{Sequence analysis}

The sequences obtained from the ITS region of all Alternaria isolates were subjected to NCBI (www.ncbi.nlm.nih.gov) BLAST search and the sequences showing highest scores were retrieved. The phylogenetic tree was generated using the neighbour joining method to estimate evolutionary distances.

\section{Analysis of pathogenic variability}

In order to test aggressiveness, the cultures were inoculated on tomato seedlings grown in pots filled with sterile potting mixture (Soil: Sand: well decomposed farm yard manure at ratio 2:1:1). For this study cultivarsPKM-1 seedlings were raised in pots. After25 days, seedlings were transplanted in $30 \mathrm{~cm}$ diameter pots.

Three seedlings were planted at equal distance in each pot. After 20 days of transplanting (45 days old), the plants were spray inoculated with spore suspension of fungal cultures. For preparation of spore suspension, the cultures were established on readymade $\mathrm{V}-8$ agar medium containing asparagine as described in spore characterization study.

After 10 days, culture mat was harvested by applying10-15 $\mathrm{ml}$ of sterile water and scraping the mycelial mat with spores. To harvest the spores, the content was mixed well and filtered through three layers of sterile muslin cloth. The filtrate containing spores was adjusted to $10^{5}$ spores/ml by diluting with sterile distilled water.

The spore suspension was spray inoculated on seedlings. After 5, 10 and 15 days of spray inoculation, the plants were observed for early blight development and scored for per cent disease index as described by Pandey et al., 2003.

\section{Results and Discussion}

\section{Cultural characterization}

All the isolates proved Koch's postulates. Characterization of the isolates indicated that most of the cultures were grey or brown with regular growth pattern. Regarding conidial morphologies viz., conidial length, breadth and beak length. Among the isolates, conidial length was maximum in PKM - KKR isolate followed by PKM - DHRisolate whereas others were having significantly smaller size. Similarly, significant difference was observed in beak length (Table 1).

Most of the reports available in India indicated that the early blight of tomato is caused by Alternaria solani (Kumar et al., 2008; Naik et al., 2010) but the present study showed two species of Alternaria infecting tomato and hence to further confirm, molecular based identification of Alternaria isolates was undertaken.

\section{PCR amplification and phylogenetic analysis}

The early blight pathogen isolates collected from different geographical locations were amplified by PCR using universal primer pairs ITS1/ITS4. The process resulted in amplification of $* 580$ bp in all infected tomato samples which corresponds to ITS rRNA of the fungal species. The PCR products were sequenced and nucleotide 
sequences of ITS region of all isolates of Alternariaspp were compared with the representative ITS region of selected fungal species from the GeneBank database using BLAST (Table 2 and Figure 1).

The study clearly indicated that majority of
Alternaria spp infecting tomato are Alternaria solani followed by Alternaria alternata. Similar identification of fungal pathogens through phylogenetic relationship was also successfully documented (Wang et al., 2001; Pryor and Michailides, 2002).

Table.1 Cultural and morphological characteristics of Alternaria spp infecting tomato

\begin{tabular}{|c|c|l|l|l|l|l|l|}
\hline $\begin{array}{c}\text { Alternaria } \\
\text { Isolate }\end{array}$ & $\begin{array}{c}\text { Culture } \\
\text { pigmentation }\end{array}$ & $\begin{array}{l}\text { Growth } \\
\text { pattern }\end{array}$ & $\begin{array}{c}\text { Length } \\
(\boldsymbol{\mu m})\end{array}$ & $\begin{array}{c}\text { Breadth } \\
(\boldsymbol{\mu m})\end{array}$ & $\begin{array}{c}\text { Conidia } \\
\text { Beak } \\
\text { length } \\
(\boldsymbol{\mu m})\end{array}$ & $\begin{array}{c}\text { Horizontal } \\
\text { septa }\end{array}$ & $\begin{array}{c}\text { Vertical } \\
\text { septa }\end{array}$ \\
\hline PKM-CBE & Yellowish grey & Regular & 31.4 & 17.1 & 12.9 & 4.1 & 2.4 \\
\hline PKM-DHR & Grey & Regular & 42.9 & 25.0 & 16.1 & 5.6 & 3.2 \\
\hline PKM-DKL & Dark grey & Regular & 36.3 & 19.8 & 13.3 & 4.4 & 2.1 \\
\hline PKM - & Brown & Regular & 45.7 & 28.2 & 19.0 & 6.2 & 3.5 \\
\hline KKR & Mean & & 39.08 & 22.53 & 15.34 & 5.08 & 2.80 \\
\hline & SEd & & 0.94 & 0.57 & 0.27 & 0.15 & 0.03 \\
\hline & C D at 5\% & & 2.17 & 1.32 & 0.63 & 0.34 & 0.07 \\
\hline
\end{tabular}

Table.2 Alternaria isolates identified based on ITS sequencing and their NCBI accession numbers

\begin{tabular}{|c|c|c|}
\hline c & Species & NCBI accession number \\
\hline PKM-CBE & Alternaria solani & MN080230 \\
\hline PKM-DHR & Alternaria solani & MN080225 \\
\hline PKM-DKL & Alternaria solani & MN080229 \\
\hline PKM - KKR & Alternaria alternata & MN080226 \\
\hline
\end{tabular}

Table.3 Disease scale description of early blight of tomato

\begin{tabular}{|c|c|}
\hline Scale & Leaf area infected $(\boldsymbol{\%})$ \\
\hline $\mathbf{0}$ & Disease free \\
\hline $\mathbf{1}$ & $1-10 \%$ \\
\hline $\mathbf{2}$ & $11-25 \%$ \\
\hline $\mathbf{3}$ & $26-50 \%$ \\
\hline $\mathbf{4}$ & $51-75 \%$ \\
\hline $\mathbf{5}$ & $>76 \%$ \\
\hline
\end{tabular}


Table.4 Aggressiveness of Alternaria isolates on tomato cultivar PKM 1

\begin{tabular}{|l|l|c|c|c|c|}
\hline \multirow{2}{*}{ Isolate } & Species & \multicolumn{3}{|c|}{ Percent Disease Incidence } & Virulence \\
\cline { 3 - 6 } & & 5 DAI & 10 DAI & 15 DAI & category \\
\hline PKM-CBE & Alternaria solani & 16.9 & 38.3 & 78.1 & Virulent \\
\hline PKM-DHR & Alternaria solani & 21.2 & 46.9 & 86.3 & Virulent \\
\hline PKM-DKL & Alternaria solani & 17.1 & 37.8 & 75.9 & Virulent \\
\hline PKM - KKR & Alternaria alternata & 19.9 & 43.4 & 80.5 & Virulent \\
\hline & Mean & 18.78 & 41.60 & 80.20 & \\
\hline & SEd & 0.29 & 0.67 & 1.14 & \\
\hline & C D at 5\% & 0.66 & 1.55 & 2.61 & \\
\hline
\end{tabular}

* DAI - Days after Inoculation

Fig.1 Phylogenetic tree showing relationships among the Alternaria spp based on their ITS sequences

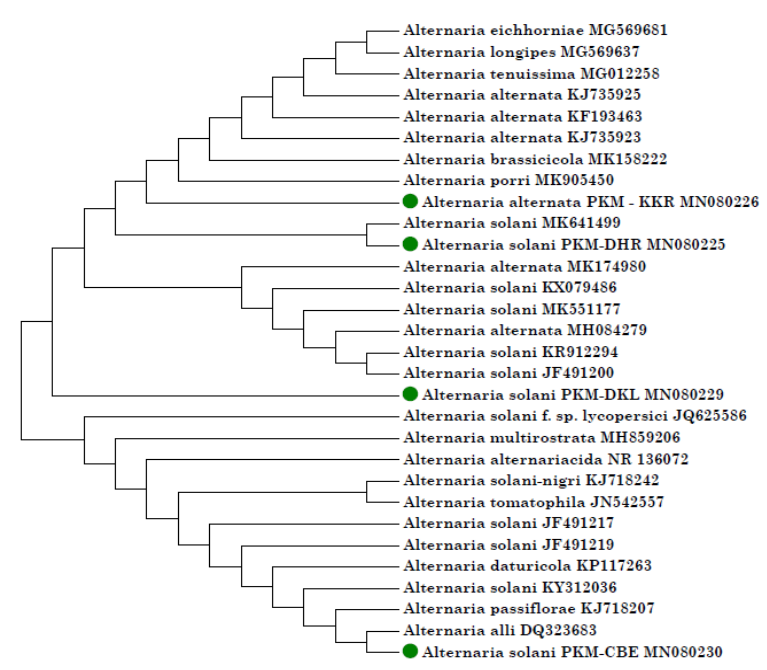

Aggressiveness of Alternaria solani and Alternaria alternata on Tomato cultivar PKM 1

Though two species Alternaria solani and Alternaria alternata were observed in association of early blight of tomato, it is essential to study their potentiality to cause disease because in many instances these species exists as saprophytes or weak parasite or opportunistic pathogen (Guo et al., 2004). Observations on virulence of different isolates of Alternaria solani and Alternaria alternata revealed that the species could produce similar kind of reaction on tomato cultivar
PKM 1 (Table 3 and 4). However, the isolates belonging to same species manifested observable variation in pathogenicity. The study indicated that both Alternaria solani and Alternaria alternata exist as a virulent form to cause early blight disease in tomato as documented earlier (Kumar et al., 2008; Naiket al., 2010). Murugan et al., (2014) and Bhatt et al., (2000) have reported the association of Alternaria alternata with early blight disease of tomato.

In conclusion the molecular and pathogenic characterization of Alternaria spp infecting tomato in Tamilnadu revealed the presence of 
Alternaria solani and Alternaria alternata in virulent form and it emphasized that both Alternaria species needs to be considered for future early blight management or resistance breeding programmes.

\section{References}

Alhussan KM (2012) Morphological and physiological characterization of Alternaria solani isolated from tomato in Jordan Valley. Res J Biol Sci 7: 316-319.

Bhatt JC, Gahlain A, Pant SK (2000) Record of Alternaria alternate on tomato, capsicum and spinach in Kumaon hills. Indian Phytopathol 53:495-496.

Bowmann KD, Albrecht U, Graham JH, Bright DB (2007) Detection of Phytophtora nicotianae and $P$. palmivora in citrus roots using PCRRFLP in comparison with other methods. Eur J Plant Pathol 119:143158.

Bridge PD, Singh T, Arora DK (2004) The application of molecular markers in the epidemiology of plant pathogenic fungi. In: Arora DK, Bridge PD, Bhatnagar D (eds) Fungal biotechnology in agricultural, food, and environmental applications. Marcel Dekker Inc, New York, p 475.

Datar VV, Mayee CD (1981) Assessment of loss in tomato yield due to early blight. Indian Phytopathol 34:191195.

Derbalah AS, El-Mahrouk MS, El-Sayed AB (2011) Efficacy and safety of some plant extracts against tomato early blight disease caused by Alternaria solani. Plant Pathol J 10(3):115-121.

Guo LD, Xu L, Zheng WH, Hyde KD (2004) Genetic variation of Alternaria alternata, an endophytic fungus isolated from Pinustabulaeformis as determined by random amplified microsatellites (RAMS). Fungal Diversity 16:53-65.

Kumar V, Haldar S, Pandey KK, Singh RP, Singh AK, Singh PC (2008) Cultural, morphological, pathogenic and molecular variability amongst tomato isolates of Alternaria solani in india. World J Microbiol Biotechnol 24:1003-1009.

Manicom BQ, Bar-Joseph M, Rosner A, Vigodsky-Haas H, Kotze JM (1987) Potential applications of random DNA probes, and restriction fragment length polymorphisms in the taxonomy of Fusaria. Phytopathology 77:669-672.

MuruganLoganathan ,V. Venkataravanappa, Sujoy Saha, Awadhesh Bahadur Rai, SwapnilaTripathi, Rakesh Kumar Rai, Atul Kumar Pandey and P. Chowdappa (2014) Morphological, Pathogenic and Molecular Characterizations of Alternaria Species Causing Early Blight of Tomato in Northern India. Proc. Natl. Acad. Sci., India, Sect. B Biol. Sci.

Naik MK, Prasad Y, Bhat KV, Devika Rani GS (2010) Morphological, physiological, pathogenic and molecular variability among isolates of Alternaria solani from tomato. Indian Phytopathology 63:168-173.

Pandey KK, Pandey PK, Kallo G, Banerjee MK (2003) Resistance to early blight of tomato with respect to various parameters of disease epidemics. J Gen Plant Pathol 69:364-371.

Pryor BM, Michailides TJ (2002) Morphological, pathogenic, and molecular characterization of Alternaria isolates associated with Alternaria late blight of pistachio. Phytopathology 92:406-416.

Wang HK, Zhang TY, Zhang M (2001) Application of sequencing of $5.8 \mathrm{~S}$ rDNA, ITS1 and ITS2 on identification and classification of 
Alternaria at species level. DH, Sninsky JJ, White TJ (eds) PCR Mycosystema 20:168-173 Protocols: a Guide to methods and White TJ, Bruns T, Lee S, Taylor JW (1990) applications. Academic Press Inc, Amplification and direct sequencing of fungal ribosomal RNA genes for phylogenetics. In: Innis MA, Gelfand

\section{How to cite this article:}

Ragupathi, K. P., P. R. Renganayaki, S. Sundareswaran, S. Mohan Kumar and Kamalakannan, A. 2020. Characterization of Alternaria Species Causing Early Blight of Tomato. Int.J.Curr.Microbiol.App.Sci. 9(12): 2603-2609.

doi: https://doi.org/10.20546/ijcmas.2020.912.308 